\title{
ЛІТЕРАТУРОЗНАВЧА ПОЛОНІСТИКА НА КАФЕДРІ СВІТОВОЇ ЛІТЕРАТУРИ І ПОРІВНЯЛЬНОГО ЛІТЕРАТУРОЗНАВСТВА ПРИКАРПАТСЬКОГО НАЦІОНАЛЬНОГО УНІВЕРСИТЕТУ ІМЕНІ ВАСИЛЯ СТЕФАНИКА (БІБЛІОГРАФІЯ ПРАЦЬ 31997 ДО ПОЧАТКУ 2020 РОКУ)
}

\author{
Ігор Козлик \\ (упорядник)
}

\author{
Доктор філологічних наук, професор, завідувач кафедри, \\ Кафедра світової літератури і порівняльного літературознавства, \\ Прикарпатський національний університет імені Василя Стефаника (УКРАЇНА), \\ 76018, м. Івано-Франківськ, вул. Шевченка, 57, \\ e-mail: ihor.kozlyk@pnu.edu.ua
}

\section{PЕФЕРАТ}

У бібліографічному покажчику представлено науковий і навчально-методичний доробок працівників кафедри світової літератури і порівняльного літературознавства у галузі літературознавчої полоністики у період з 1997 року, тобто з часу першої публікації після відкриття на Факультеті філології ПНУ імені Василя Стефаника відділення полоністики й аспірантури з порівняльного літературознавства при кафедрі світової літератури, і до початку 2020 року включно. Джерела розташовані у хронологічному порядку (в межах років в алфавітному порядку) і описані у відповідності до Національного стандарту України ДСТУ 8302:2015.

Ключові слова: полоністика, українська полоністика, кафедра світової літератури і порівняльного літературознавства ПНУ імені Василя Стефаника.

\section{POLISH LITERARY STUDIES IN THE DEPARTMENT OF WORLD LITERATURE AND COMPARATIVE LITERARY CRITICISM OF VASYL STEFANYK PRECARPATHIAN NATIONAL UNIVERSITY (BIBLIOGRAPHY OF WORKS FROM 1997 TO THE BEGINNING OF 2020)}

\section{Ihor Kozlyk (Compiler)}

\author{
Professor Doctor Habilitatus of Philology, Head of Department, \\ Department of World Literature and Comparative Literary Criticism, \\ Vasyl Stefanyk Precarpathian National University (UKRAINE), \\ 76018, Ivano-Frankivsk, 57, Shevchenko str., \\ e-mail: ihor.kozlyk@pnu.edu.ua
}

\footnotetext{
ABSTRACT

The bibliographic index presents the academic, educational and methodological achievements of the members of the Department of World Literature and Comparative Literary Criticism in the field of Polish literary studies in the period since 1997, i.e. from the first publication after the opening of the branch of Polish Studies and the postgraduate division at the Department of World Literature of the Faculty of Philology of Vasyl Stefanyk Precarpathian National University, and to the beginning of 2020. The sources are arranged in chronological order (and in alphabetical order within each year) and described in accordance with the National Standard of Ukraine.

Key words: polish literary studies, Ukrainian polish literary studies, Department of World Literature and Comparative Literary Criticism of Vasyl Stefanyk PNU.
} 
Літературознавче вивчення польської літератури на кафедрі світової літератури і порівняльного літературознавства ПНУ імені Василя Стефаника було започатковане в умовах, які виникли після створення 26 серпня 1992 року на базі Івано-Франківського державного педагогічного інституту імені В. С. Стефаника Прикарпатського університету імені Василя Стефаника та відкриття наступного 1993 року на філологічному факультеті цього вишу спеціальності «Польська мова і література», що вимагало наявності власних фахівців-полоністів.

Проте розгортання наукової літературознавчої полоністики безпосередньо пов'язане з відкриттям при кафедрі світової літератури у листопаді 1993 року аспірантури 3 літературознавчих дисциплін, а 3 квітня 2001 року аспірантури 3 порівняльного літературознавства, що стало можливим лише після того, як кафедру у 1992 році очолив доктор філологічних наук, професор Володимир Григорович Матвіїшин (1935-2012). Він заохочував своїх підлеглих займатися компаративними дослідженнями зарубіжних, у тому числі слов'янських, літератур (насамперед в аспекті українсько-зарубіжних літературних зв'язків), а також спеціальним дослідження конкретної, в тому числі і польської, національної словесності в іманентній площині.

\section{7}

1. Kozłyk I. Проблема культурного пограниччя на сторінках преси Галичини кінця XIX - початку XX століття. Acta Polono-Ruthenica. Olsztyn, 1997. T. II. S. 385-391.

\section{8}

2. Теплінський М. В. «Кримські сонети» - «чисте золото поезії». Всесвітня літ. $в$ середніх. навч. закл. України. [Київ] 1998. № 12. С. 19-21.

3. Цивкач О. М. К вопросу о литературных традициях в поэме А. Мицкевича «Пан Тадеуш». Адам Мічкевич $і$ Україна : матеріали міжнар. наук. конф., присвяченої 200-річчю від дня народження видатного польського поета. Дрогобич, 1998. С. 44-48.

4. Цівкач О. М. Проблематика «малої» прози Я. Івашкевича: На матеріалі оповідань «Панночки з Вінчиків» та «Ікар». Джерела. [Івано-Франківськ] 1998. № 2. С. 26-28.

5. Цівкач О. М. «Сизиф прикутий до пекла поезії...» (Про поезію В. Шимборської). Відродження. [Київ] 1998. № 1. С. 36-41.

6. Цивкач О. М. Творчество Адама Мицкевича в свете концепции Д. Н. ОвсяникоКуликовского о психологи гениальности. Вісник Харківського ун-ту. Філологія. Харків, 1998. № 411 : Спадщина Д. М. Овсянико-Куліковського та сучасна філологія. С. 49-53.

\section{9}

7. Матвї̈шин В. Г. «Найбільший поет польської нації...» (Франко про А. Міцкевича). До 200-річчя від дня народження Адама Міцкевича. Обрії. [Івано-Франківськ] 1999. № 1(8). C. 61-68.

8. Teplinsky М. Про сонети А. Міцкевича і переклади М. Рильського. Acta PolonoRuthenica. Olsztyn : Wydawnictwo Uniwersytetu Warmińsko-Mazurskiego, 1999. T. IV. S. 34-48.

\section{0}

9. Медицька М. Полісемія міфологеми «Сhochol» у драмі «Весілля» Станіслава Виспянського. Семантика мови і тексту: зб. статей VI Міжнар. конф. Івано-Франківськ : Плай, 2000. С. 608-612.

10. Ciwkacz O., Tomchak A. Ukraińskie thumaczenia utworów Henryka Sienkiewicza w drugiej połowie XIX wieku i na początku XX wieku. Семантика мови і тексту : зб. статей VI міжнар. конф. Івано-Франківськ, 2000. С. 650-660. 


\section{1}

11. Ткачук Т. Станіслав Пшибишевський поза національними кордонами (на матеріалі хорватської критики і літератури). Вісник Прикарпатського ун-ту. Філологія. ІваноФранківськ : Плай, 2001. Вип. 6. С. 181-189.

12. Ciwkacz O. Tajemnicza polska pieśń. Pierwszy przekład poezji Franciszka Karpińskiego na język ukraiński (Do Justyny. Tęsknośc na wiośnę). Wiek Oświecenia. Warszawa, 2001. Nr 17. S. 159-167.

\section{2}

13. Козлик I. В. Творчість Францішка Карпінського: підсумки і перспективи вивчення. Сівач духовності : зб. спогадів, статей і матеріалів, присвячений професору Володимирові Полєку. Івано-Франківськ : Плай, 2002. С. 284-296.

14. Медицька М. С. Фольклорно-міфологічна основа драми «Легенда» Станіслава Виспянського і «Лісова пісня» Лесі Українки. Зарубіж. літ. в навч. закл. [Київ] 2002, № 2. C. 33-37.

15. Медицька М. С. Художнє мислення С. Виспянського: філософія смерті. Вісник Київского нац. ун-ту імені Тараса Шевченка. Літературознавство. Мовознавство. Фольклористика. Київ, 2002. Вип. 12. С. 40-44.

16. Ткачук Т. Літературно-естетичні погляди Станіслава Пшибишевського. Питання літературознавства. Чернівці, 2002. Вип. 9(66). С. 123-125.

17. Ткачук Т. Модерністичні тенденції Станіслава Пшибишевського в рецепції українських майстрів слова. Українська література в загальноєвропейському контексті. Ужгород : Ліра, 2002. Вип. 5. С. 171-176.

18. Ciwkacz O. «Jestem dzieckiem kraju huculskiego...» (obraz Huculszczyzny w listach Stanisława Vincenza). Płaj. Almanach Karpacki. Pótrocznik Towarzystw Karpackiego. Warszawa, 2002. Nr 25. S. 63-74.

\section{3}

19. Мартирець А. М. Образ дитини в літературній спадщині Януша Корчака як ключ до розуміння школяра. Міжнар. науково-практ. конф. «Гуманістичні ідеї педагогічної спадщини Януша Корчака в XXI столітmі», Київ : Наук. світ, 2003. С. 100-104.

20. Медицька М. С. Творчість Станіслава Виспянського в літературознавчих концепціях Ярослава Гординського. Вісник Прикарпатського ун-ту. Філологія. Івано-Франківськ : Плай, 2003. Вип. 8. С. 142-148.

21. Медицька М. С. Художня інтерпретація бібілйних мотивів та образів у творчості Станіслава Виспянського та Лесі Українки. Українознавчі студії. Івано-Франківськ, 2002-2003. № 4-5. С. 152-162.

22. Медицька М. С. Художня рецепція і трансформація античної «Мойри» в драматургії Станіслава Виспянського та Лесі Українки. Київські полоністичні студї. Київ, 2003. T. V : Романтизм : між Україною та Польщею. С. 398-409.

23. Цивкач О. М. Из истории переписки Станислава Винценза и украинской писательницы Ольги Дучиминской. Исследование славянских языков и литератур в высшей школе: достижения и перспективы : сб. материалов междунар. науч. конф. Москва : Издательство МГУ, 2003. С. 155-165.

24. Цивкач О. М. К вопросу о восприятии традиций европейской культуры в эссеистике Станислава Винценза. Материаль междунар. славистич. конф. Москва, 2003. C. $177-185$.

25. Цівкач О. М. Станіслав Вінценз і Гуцульщина. Матеріали IV міжнар. конф. «Гуцульщинна: минулу і майбутнє». Івано-Франківськ : Плай, 2003. С. 67-77. 
26. Ciwkacz O. Literatura polska na stronicach «Literaturno-naukowego Wistnyka». Kraków - Lwów XIX-XX w. Książi, czasopisma, biblioteki / pod red. prof. Jerzego Jarowieckiego. Kraków, 2003. T. VI. Cz. 2. S. 155-163.

27. Stefania Skwarczyńska jako recenzent teatralny i felietonistka «Kurjera Stanisławowskiego». Kultura i świadomość etniczna Polaków na Wschodzie. Tradycja i wspótczesność: Materiały. Wrocław, 2003. S. 117-130.

\section{4}

28. Цівкач О. М. До питання про перші переклади творів Анджея Немоєвського українською мовою. Семантика мови $і$ тексту : зб. статей VIII міжнар. наук. конф. Івано-Франківськ : Плай, 2004. С. 531-539.

29. Ziwkatsch O. Kulturen Leben im Stanislau der Zwischenkrigszeit. Die Ukraine, Polen und Europa : Europäische Identität an der neuen EU-Ostgrence. Osnabrük : «Fibre», 2004. S. 277-287.

\section{5}

30. Kozłyk I. Проблема культурного пограниччя: спроба теоретичної ідентифікації. Acta Polono-Ruthenica. Olsztyn : Wydawnictwo Uniwersytetu Warmińsko-Mazurskiego, 2005. T. X. S. 9-20. URL: http://bazhum.muzhp.pl/media//files/ Acta_Polono_Ruthenica/Acta_Polo no_Ruthenica-r2005-t10/Acta_Polono_Ruthenica-r2005-t10-s7-20/Acta_Polono_Ruthenica-r20 05-t10-s7-20.pdf

31. Матвіїшин В. Г. Польська література у перекладацькій спадщині Миколи Зерова. Studia Ucrainica. Warszawskie Zeszyty Ukrainoznawcze. Польсько-українські зустрічі / за ред. Стефана Козака ; Кафедра україністики Варшавського ун-ту. Варшава, 2005. Т. 19-20. С. 240-252.

32. Медицька М. С. Експлікація екзистенційних мотивів та образів у поезії Станіслава Виспянського і Петра Карманського : типологія художніх моделей. Warszawskie zeszyty ukrainoznawcze. Warszawa, 2005. Nr 19-20. S. 210-228.

33. Медицька М. С. Парадигма України у творчості Станіслава Виспянського. Київські полоністичні студї. Київ, 2005. Т. VII : «Українська школа» в літературі та культурі українсько-польського пограниччя. С. 423-433.

34. Ткачук Т. Генеза і типологія раннього українського і польського модернізму (кін. XIX - поч. XX ст.). Studia Methodologica. Тернопіль, 2005. Вип. 15. С. 100-108.

35. Цівкач О. М. До питання про своєрідність пародій Стефанії Скварчинської. $3 б$. наук. працъь Полтавського пед. ін-ту. Полтава, 2005. С. 38-47.

36. Цівкач О. М. «Я листа зустрічаю мов гостя». Листування Станіслава та Ірени Вінценз з Ольгою Дучимінською. Нова Польщяа. Спеціальний український номер. Варшава, 2005. № 9. С. 65-72.

37. Ciwkacz O. Dzieje Biblioteki miejskiej im. W. N. Smaglowskiego w Stanisławowie (1872-1939). Folio Librorum. Łódź, 2005. Nr 13. S. 21-31.

38. Ciwkacz O. Obraz Huculszczyzny w listach Stanisława Vincenza // Napis. Tom poświęcony literaturze okolicznościowej i użytkowej. Seria XI, Warszawa 2005. S. 289-300.

39. Ciwkacz O. Turysta (z genezy «Książki o Kołymie» Anatola Krakowieckiego). Zestaniec. Wrocław, 2005. Nr 21. S. 37-47.

40. Ciwkacz O. Z dziejów opery amatorskiej Towarzystwa Muzycznego im. St. Moniuszki w Stanisławowie (1871-1914). Galicyjskie spotkania 2005 / tom studiów pod red. prof. dr hab. Urszuli Jakubowskiej, Fundacja Dziedzictwo im. Chone Shmeruka. Kalisz : Agencja Wydawnicza «Sztuka i Rynek», 2005. S. 39-60.

41. Ciwkacz O. Z recepcji i przekładów utworów Mikołaja Reja na Ukrainie. Mikołaj Rej - w pięćsetlecie urodzin. : w 2-ch t. Łódź / praca zbiorowa pod red. Jana Okonia. Przy 
współpracy Marcina Bauera, Michała Kurana i Małgorzaty Mieszek. Łódź : Wydawnictwo Uniwersytetu Łódźkiego, 2005. T. 2. S. 289-304.

\section{6}

42. Матвіїшин В. Г. Іван Франко і поетика натуралізму в контексті українськопольських літературних взаємин XIX століття. Studia Ucrainica. Warszawskie Zeszyty Ukrainoznawcze. Україна. Тексти i контексти : книга на пошану професора Стефана Козака 3 нагоди його ювілею сімдесятиліття / кафедра україністики Варшавського ун-ту. Варшава, 2007. Т. 21-22. С. 349-361.

43. Медицька М. С. Гротескний театр Станіслава Ігнація Віткевича : реальність і парадокс. Зарубіж. літ. в навч. закл. [Київ] 2006. № 6. С. 61-64.

44. Медицька М. С. Драми «Визволення» Станіслава Виспянського і «Золоті ворота» Василя Пачовського: типологія образних алюзій та містифікацій. Сучасні проблеми мовознавства та літературознавства : матеріали міжнар. наук. конф. «Українська література в загальноєвропейському контексті», Ужгород, 10-12 жовтня 2005 р. Ужгород, 2006. Вип. 9. С. 219-228.

45. Медицька М. С. Цінне дослідження [Рец. на: Włodzimierz Mokry. Ukraina Wasyla Stefanyka, Kraków, 2001, 256 s.]. Етнос і культура. [Івано-Франківськ] 2005-2006. № 2-3. C. 280-281.

46. Спатар І. Іван Франко та Еліза Ожешко: взаємини, рецепція, переклади (на матеріалі листів Івана Франка та Елізи Ожешко, перекладених Михайлом Возняком). Волинь-Житомирщина. Історико-філол. зб. з регіональних проблем. Житомир, 2006. № 15. C. $142-147$.

47. Цивкач О. М. К вопросу о творческой истории книги Анатоля Краковецкого «Книга о Колыме». Филол. исследования. Донецк : Юго-Восток ЛТД, 2006. Вып. 8. C. $143-151$.

48. Цівкач О. М. Особливості літературно-мистецького життя Станіслава 19191939 років. Етнос $і$ культура. [Івано-Франківськ] 2006. № 10. С. 23-32.

49. Ciwkacz O. Kobiety w życiu literacko-kulturalnym Stanisławowa okresu międzywojennego. Kresowianki. Krag pisarek heroicznych. Lublin, 2006. S. 137-147.

50. Ciwkacz O. «Przyszłość zbiera z nich nasiona...»: Epizod stanisławowski Stefanii Skwarczyńskiej. Studia $i$ szkice slawistyczne / pod red. Bronisława Kodzisa; Uniwersytet Opolski; Instytut Filologii Wschodniosłowiańskiej. Opole, 2006. T. 7. S. 115-124.

51. Ciwkacz O. Teatr polski w Stanislawowie w latach 1892-1894. Galicyjskie spotkania 2006 / tom studiów pod red. prof. dr hab. Urszuli Jakubowskiej. Kalisz : Agencja Wydawnicza «Sztuka i Rynek», 2006. S. 49-80.

52. Ciwkacz O. Z dziejów prasy stanisławowskiej. Семантика мови і тексту: матеріали IX міжнар. наук.-практ. конф. Івано-Франківськ, 2006. С. 552-562.

\section{7}

53. Медицька М. С. Драматургія Сжи Шанявського : конфлікти і характери. Вісник Прикарпатського ун-ту. Філологія. Івано-Франківськ, 2007. Вип. 13-14. С. 141-148.

54. Спатар I. Внутрішній світ людини в оповіданнях Івана Франка «На дні» та Елізи Ожешко «Зимового вечора» : спроба типологічного аналізу. Наукові праці Кам'янець-Подільського держ. ун-ту. Філологічні науки. Кам'янець-Подільський, 2007. Вип. 14. Т. 2. С. 202-210.

55. Спатар I. Творчість Осипа Маковея та Елізи Ожешко : характерологічна спільність і відмінність. Вісник Прикарпатського ун-ту. Філологія (літературознавство). Івано-Франківськ : ПНУ, 2006-2007. Вип. 13-14. С. 175-179.

56. Ткачук Т. Драми С. Пшибишевського «Сніг», В. Винниченка «Чорна Пантера і Білий Медвідь» та оповідання В. Пачовського «Жертва штуки» : типологічні паралелі. 
Наук. праці Кам'янець-Подільського держ. ун-ту. Філол. науки. Кам'янець-Подільський : Абетка-НОВА, 2007. Вип. 14. Т. 2. С. 232-248.

57. Ткачук Т. Стильова спорідненість драм Станіслава Пшибишевського «Сніг», Володимира Винниченка «Чорна Пантера і Білий Ведмідь» та оповідання «Жертва штуки» Василя Пачовського. Вісник Прикарпатського ун-ту. Філологія (літературознавство). Івано-Франківськ : ПНУ, 2006-2007. Вип. 13-14. С. 190-198.

58. Ткачук Т. Художня інтерпретація мотиву смерті у прозі С. Пшибишевського та В. Стефаника. Питання літературознавства. Чернівці : Рута, 2007. Вип. 74. С. 286-301.

59. Ciwkacz О. Станіславів - місто трьох театрів (1919-1939). Pogranicze: Obsesje Projekscje-Projekty. Chełm, 2007. S. 349-357.

\section{8}

60. Матвіїшин В. Г. «...Найбільший поет польської нації ...» (Іван Франко про Адама Міцкевича). Зарубіж. літ. в школах Украӥни. [Київ] 2008. № 11. С. 2-9.

61. Медицька М. С. Стильові означення творчості Станіслава Виспянського польськими дослідниками. Київські полоністичні студії. Київ, 2008. Т. Х. С. 497-510.

62. Медицька М. С. Творчість Станіслава Виспянського й українська література кінця XIX - початку XX століття : рецепція і типологія / наук. ред. В. Г. Матвї̈шин. Івано-Франківськ : Видавець Третяк І. Я., 2008. 316 с.

63. Спатар I. Переклади творів Елізи Ожешко в українській літературі. Вісник Харківського нац. ун-ту ім. В. Н. Каразіна. Філологія (літературознавство). Харків, 2008. Вип. 54. № 836. С. 286-290.

64. Спатар I. «Слово про Елізу Ожешко» або до проблеми взаємозв'язків Елізи Ожешко з українськими письменниками. Вісник Прикарпатського ун-ту. Філологія (літературознавство). Івано-Франківськ : ПНУ, 2008. Вип. 15-16. С. 182-187.

65. Спатар I. Творчість Елізи Ожешко в літературно-критичній рецепції Олени Пчілки. Література. Фольклор. Проблеми поетики. Київ, 2008. Вип. 31. Ч. 2. С. 673-682.

66. Спатар I. Типологія малої прози Олександра Кониського та Елізи Ожешко крізь призму національних культур. Мова $і$ культура. Київ : Видавничий дім Дмитра Бураго, 2008. Вип. 10. Т. VIII(108). С. 148-155.

67. Спатар I. Типологія художніх креацій Елізи Ожешко та Осипа Маковея (на матеріалі збірок «GloriaVictis» й «Кроваве поле». Актуальні проблеми сучасної філології. Літературознавство. Рівне, 2008. Вип. 18. С. 163-173.

68. Ткачук Т. Особливості художнього мислення Станіслава Пшибишевського та Ольги Кобилянської. Вісник Прикарпатського ун-ту. Філологія (літературознавство). Івано-Франківськ : ПНУ, 2008. Вип. 17-18. С. 160-168.

69. Ткачук Т. Синтез мистецтв у творчості Станіслава Пшибишевського та Ольги Кобилянської. Українознавчі студії. Івано-Франківськ : ПНУ, 2007-2008. № 8-9. С. 479491.

70. Цівкач О. М. Іван Франко у рецепції Станіслава Вінценза. Сторінки невідомих спогадів. «Для добра мільйонів хай вічно живе...» : зб. наук. праць на пошану 150-річчя від дня народження Івана Франка. Івано-Франківськ, 2008. С. 225-235.

71. Цівкач О. М. Образ Гуцульщини у листуванні Станіслава Вінценза. Вінцензіана. Коломия, 2008. С. 68-80.

72. Цивкач О. Турист (к вопросу о творческой истории «Книги о Колыме» Анатоля Краковецкого). Новая Польша. Варшава, 2008. № 6(98). С. 42-44.

73. Ciwkacz O. 3 історії листування Станіслава та Ірини Вінцензів з українською письменницею Ольгою Дучимінською. Galicyjskie spotkania 2007 / tom studjuw pod redakcją prof. dr hab. Urszuli Jakubowskiej, Fundacja Dziedzictwo im. Chome Shmeruka; Instytut Badań Literackich PAN. Kalisz, 2008. S. 153-171. 
74. Ciwkacz O. Kornel Makuszyński jako recenzent teatralny «Słowa Polskiego» (19051909). Literaturoznawstwo : Historia-teoria-metodologia-krytyka. Łodź, 2008. Nr 1(2). S. 7792.

75. Ciwkacz O. Ormianie w życiu literacko-kulturalnym Stanisławowa (XIX-XX w.). III Dni Kultury Ormiańskiej w Gliwicach. Gliwice, 2008. S. 48-58.

76. Ciwkacz O. «Przygody» bohaterów Józefa Weyssenhoffa, Henryka Sienkiewicza i Gabrieli Zapolskiej w satyrycznych felietonach Stefanii Skwarczyńskiej («Kurier Stanisławowski» 1926-1929). Józef Weyssenhoff $i$ Leon Wyczółkowski. Obrazy Kultury Polskiej. Lublin, 2008. S. 225-237.

\section{9}

77. Козлик I. В. [Рец. на: Нахлік Є. Доля - Los - Судьба : Шевченко і польські та російські романтики / НАН України. Львівське відділення Інституту літератури ім. Т. Г. Шевченка]. Записки Наукового товариства імені Шевченка. Львів, 2009. T. CCLVII : Праці Філологічної секції. С. 702-707.

78. Матвіїшин В. Г. Адам Міцкевич і літературний процес в Україні. Матвїшин В. Г. Український літературний європеїзм. Київ : Видавничий центр «Академія», 2009. C. $36-46$.

79. Матвіїшин В. Г. Діяльність Павлина Свенцицького в контексті українськопольських міжлітературних взаємин. Матвїшин В. Г. Украӥнський літературний європеїзм. Київ : Видавничий центр «Академія», 2009. С. 46-53.

80. Матвіїшин В. Г. Польська література у транслятологічній проекції Миколи Зерова. Матвїиин В. Г. Український літературний європеїзм. Київ : Видавничий центр «Академія», 2009. С. 119-128.

81. Медицька М. С. Художня парадигма маски в прозі Вітольда Гомбровича та Григора Тютюнника: текст і контекст. Київькі полоністичні студї. Київ, 2009. Т. XVI. C. $369-380$.

82 Микитин I. Творчість Юрія Федьковича в рецепції Каєтана Абгаровича. Galicyjskie Spotkania 2008 : tom studiyw / [pod red. U. Jakubowskiej] / Fundacja Dziedzictwo im. Chone Shmeruka ; Instytut Badac Literackich. Zabrze : Wydawnictwo Inforteditions, 2009.

83. Спатар I. Еліза Ожешко та Україна крізь призму літературних зв’язків (на матеріалі взаємного листування Елізи Ожешко й Олександра Кониського) Феномен памежжа. Славянскія мовы, літаратуры і культуры: этнас у свеце гісторыі і сучаснасиі : зб. навук. прац ГрдУ імя Я. Купалы. Гродна, 2009. С. 97-105.

84. Спатар I. Жанрово-стильові особливості малої прози Елізи Ожешко та Осипа Маковея. Східнослов'янська філологія. Літературознавство. Горлівка, 2009. Вип. 14. C. 245-254.

85. Спатар I. Рецептивна модель як домінанта дитячого світосприймання у творах про дітей Елізи Ожешко та Івана Франка. Актуальні проблеми слов'янської філології. Бердянськ, 2009. Вип. 21. С. 188-199.

86. Цівкач О. М. 3 історії польського театру у Станіславові (1933-1939). Слово. Прикарпатський вісник НТШ. Івано-Франківськ, 2009. № 2(6). С. 244-254.

87. Ciwkacz O. Helena Modrzejewska w Stanisławowie. Galicyjskie spotkania 2009 / tom studiów pod red. prof. dr hab. Urszuli Jakubowskiej; Fundacja Dziedzictwo im. Chone Shmeruka; Instytut Badań Literackich PAN. Kalisz, 2009. S. 197-211.

88. Ciwkacz O. Słowo i scena. Z dziejów teatru polskiego w Stanisławowie (18671894). Przez Słowo - w słowach - o słowach / pod red. ks. Tadeusza Borutki i prof. Anny Węgrzyniak przy współudziale Angeliki Matuszek; Akademia Techniczno-Humanistyczna w Bielsku-Białej. Bielsko-Biała : ATH, 2009. S. 258-272. 
89. Ciwkacz O. Uroki tolerancji, czyli o życiu teatralnym Stanisławowa (1919-1939). Pogranicze kulturowe : odrebność-wymiana-przemykanie-dialog. Rzeszów : Wydawnictwo uniwersytetu Rzeszowskiego : Biblioteka «Frazy», 2009. S. 450-460.

\section{0}

90. Козлик И. В. Доброта как способ жить и творить [На пам’ять про проф. Б. Я. Бялокозовича]. Slawista : biuletyn informacyjny Instytutu neofilologii Uniwersytetu Warmińsko-Mazurskiego w Olsztynie. Nr 26 - specjalny, kwiecień 2010. S. 9-14. URL: https: //docplayer.pl/115946555-Slawista-numer-poswiecony-pamieci-profesora-bazylego-bialokozo wicz a.html

91. Козлик І. В. Поетична іронія і проблема ідентифікації лірики В. Шимборської. Наук. вісник Волинського нац. ун-ту імені Лесі Украӥнки. Філол. науки: літературознавство. Луцьк, 2010. Вип. 11. С. 89-95. URL: http://eprints.zu.edu.ua/10142/1/Астрахан\%20 Н.І.Літературний\%20твір\%20як\%20модель\%20семіоз ису.pdf

92. Медицька М. С. Національна минувшина в художньому осмисленні Івана Франка та Станіслава Виспянського. Радишевський Р. Українська полоністика: проблеми, иколи, сильвети. Київ, 2010. С. 548-557.

93. Медицька М. С. Художня парадигма маски: літературний контекст Заходу i Сходу (на матеріалі прози Л. Піранделло, Г. Гессе, В. Гомбровича, Г. Тютюнника). Зарубіж. літ. в школах України. [Київ] 2010. № 4. С. 2-10.

94. Микитин I. Візія мультикультурного суспільства у прозовій творчості Каєтана Абгаровича і Юрія Федьковича. Питання літературознавства. Чернівці : ЧНУ, 2010. Вип. 79. С. 189-194.

95. Микитин I. Гуцульщина Каєтана Абгаровича і Юрія Федьковича : зустріч з «іншим». Вісник Прикарпатського ун-ту. Філологія (літературознавство). Івано-Франківськ : ПНУ, 2009-2010. Вип. 23-24. С. 278-283.

96. Микитин І. Гуцульщина Каєтана Абгаровича і Юрія Федьковича: часопростір у вимірі archu. Вісник Прикарпатського ун-ту. Філологія (літературознавство). ІваноФранківськ : ПНУ, 2010. Вип. 27-28. С. 296-301.

97. Микитин I. Інтегральність образу Юрія Федьковича у творчості Каєтана Абгаровича. Південний Архів. Філол. науки. Херсон : ХДУ, 2010. Вип. XLIX. С. 93-100.

98. Микитин I. Модус пограниччя : рефлексії з приводу полівалентності літературознавчих інтерпретацій. Східнослов'янська філологія. Горлівка : ГДПІІМ, 2010. Вип. 16 : Літературознавство. С. 133-141.

99. Микитин I. Опозиція «місто / село» в гуцульському вимірі діалогу культур (на матеріалі прозової творчості Каєтана Абгаровича і Юрія Федьковича). Актуальні проблеми слов'янської філології: Лінгвістика і літературознавство. Бердянськ : БДПУ, 2010. Вип. ХXIII. Ч. III. С. 118-125.

100. Рега Д. Візуальні експерименти у творчості українських і польських футуристів. Вісник Прикарпатського ун-ту. Філологія. Івано-Франківськ : Плай, 2010. Вип. 27-28. С. 307-312.

101. Рега Д. Типологія футуристичних тенденцій у творчості Михайля Семенка та Бруно Ясенського. Вісник Прикарпатського ун-ту. Філологія. Івано-Франківськ : Плай, 2009-2010. Вип. 23-24. С. 295-299.

102. Спатар I. Фемінний тип нарації в новелістиці Елізи Ожешко й Івана Франка. Компаративні дослідження слов'янських мов і літератур. Київ, 2010. Вип. 12. С. 362370.

103. Ткачук Т. Експлікація містичних образів і мотивів у творчості М. Гоголя та С. Пшибишевського. Вісник Прикарпатського ун-ту. Філологія (літературознавство). Івано-Франківськ : ПНУ, 2009-2010. Вип. 23-24. С. 237-245. 
104. Ткачук Т. Проблема естетичного кредо митця у творчості С. Пшибишевського та українських письменників кінця XIX - початку XX століття. Викладання зарубіжної літератури : проблеми та досягнення. Султанівські читання / відп. ред. В. Г. Матвї̈ин. Івано-Франківськ : ПрутПринт, 2010. Вип. І. С. 128-129.

105. Ciwkacz О. Відома невідома історія повсякденності або «Як то було сто років тому назад?» Августа Бельовського // Galicyjskie spotkania 2010. Tom studiów pod redakcją prof. dr gab. Urszuli Jakubowskiej. Fundacja Dziedzictwo im. Chone Shmeruka. Instytut Badań Literackich. - Kalisz: Wydawnictwo inforteditions, 2010. - S. 35-50.

106. Ciwkacz O. Lwowskie «korzenie» sceny polskiej w Stanisławowie. Modernistyczny Lwów. Warszawa, 2010. S. 28-37.

107. Ciwkacz O. Skarby archiwum Kresowych : Szopka Stanisławowska z roku pańskiego MCMXXXXVII. Stan badań nad wielokulturowym dziedzictwem dawnej Rzeczypospolitej / red. nauk. Wojciech Walczak i Karol Łopacki. Białostok, 2010. T. II. S. 315-330.

108. Ciwkacz O. Twórczość Juliusza Słowackiego w czasopismach ukraińskich i drukach zwartych końca XIX i początku XX wieku (1876-1910). Folio Librorum. Łódź, 2010. Nr 46. S. 79-91.

\section{1}

109. Рега Д. Образ польського суспільства в поглядах польських футуристів. Наук. вісник Волинського наи. ун-ту імені Лесі Украӥнки. Філол. науки. Луцьк : ВНУ, 2011. Вип. 13. С. 116-121.

110. Цівкач О. М. Літературне краєзнавство. Польська література Прикарпаття (XV - перша половина XX ст.). Івано-Франківськ : Симфонія форте, 2011. Ч. 1. 272 с.

111. Цівкач О. М. Роль середньовічної релігійної драми у процесі відродження польського театру. Питання літературознавства. Чернівці : Рута, 2011. Вип. 83. С. 128131.

112. Ciwkacz O. Korespondencja Rościsława Romana Jendyka i Stanisława Vincenza. Czasopismo Zakładu Narodowego imienia Ossolińskich. Wrocław : Wrocławska Drukarnia Naukowa PAN, 2011. Zeszyt 22. S. 79-100.

113. Ciwkacz O. 3 історії польського професійного театру під керівництвом Зузани Лозинської у Станіславові (1933-1939). Galicyjskie spotkania 2011 / tom studiów pod red. prof. dr hab. Urszuli Jakubowskiej; Fundacja Dziedzictwo im. Chone Shmeruka; Instytut Badań Literackich. Kalisz : Wydawnictwo inforteditions, 2011. S. 241-256.

\section{2}

114. Медицька М. С. Рецепція Данте у польській та українській літературах крізь призму концепцій Станіслава Вінценза та Максима Стріхи. Київські полоністичні студї. Київ, 2012. Т. ХІХ. С. 81-86. (Посмертна публікація).

115. Рега Д. Ідейно-естетичні засади польського та українського футуризмів : типологічний аспект. Актуальні проблеми викладання літератури у середній та вищій школі. Султанівські читання / відп. ред. В. Г. Матвіїшин. Івано-Франківськ : Симфонія форте, 2012. Вип. II. С. 122-131.

116. Рега Д. Урбаністичні мотиви у творчості поетів-футуристів (на прикладі творчості В. Маяковського, М. Семенка та Б. Ясенського). Наукові праці Кам'янець-Подільського нац. ун-ту імені Івана Огієнка. Філол. науки. Кам'янець-Подільський : Аксіома, 2012. Вип. 29. Ч. 1. С. 185-191.

117. Спатар I. Жанротворча функція часопростору у творах Елізи Ожешко «Тадейко» та Осипа Маковея „Самота”. Актуальні проблеми викладання літератури у середній та вищій школі. Султанівські читання / відп. ред. В. Г. Матвіїшин. Івано-Франківськ, 2012. Вип. II. С. 175-184.

118. Ткачук Т. Експлікація музичних образів і мотивів у творчості С. Вінценза. Київські полоністичні студії. Київ : Ун-т «Україна», 2012. Т. 19. С. 104-109. 
119. Ткачук Т. Елементи експресіонізму у творчості Станіслава Пшибишевського та Ольги Кобилянської. Актуальні проблеми викладання літератури у середній та вищій школі. Султанівські читання / відп. ред. В. Г. Матвіїшин. Івано-Франківськ : Симфонія форте, 2012. Вип. II. С. 185-191.

120. Цівкач О. М. Їх поєднала земля станіславівська... Діячі польської культури Прикарпаття XIX - першої половини XX століття. Станіславівське воєводство. ІваноФранківськ : Симфонія форте, 2012. 204 с.

121. Цівкач О. М. Театральні рецензії Стефанії Скварчинської (1926-1929) як документ розвитку польського провінційного театру. Актуальні проблеми викладання літератури у середній та вищій школі. Султанівські читання / відп. ред. В. Г. Матвіїшин. Івано-Франківськ : Симфонія форте, 2012. Вип. II. С. 205-212.

122. Цівкач O. M. «...Przyjaciół, takich jak Pan... w ogóle nie dużo w przyrodzie» (листування Станіслава Вінценза і Ростислава Сндика). Київські полоністичні студії. Київ : Ун-т «Україна», 2012. Т. ХІХ. С. 93-98.

123. Ciwkacz O. К вопросу о функции танца в «Правде старовека» Станислава Винценза. Taniec $w$ literaturze polskiej XIX $i$ XX wieku / pod redakcja Sylwii KarpowiczSłowikowskiej i Elżbiety Mikiciuk. Gdańsk : Wydawnictwo Uniwersytetu Gdańskiego, 2012. S. 369-381.

124. Ciwkacz O. Ignacy Nikorowicz jako tłumacz poezji ormiańskiej. Na pograniczach literatury. Biblioteka Literatury Pogranicza / seria pod redakcją Andrzeja Romanowskiego. Kraków : UNIVERSITAS, 2012. T. 21. S. 427-437.

\section{3}

125. Мартинець А. Барбара Космовська. Мартинець А. Нові імена в шкільному курсі світової літератури: посібник для вчителів світової літератури та студ. філол. спеціальностей. Івано-Франківськ : Симфонія форте, 2013. С. 62-72.

126. Мартинець А. М. Екзистенція кохання через призму бачення Януша Вишневського на прикладі роману «Самотність в мережі». Актуальні проблеми слов'янської філології. Серія: лінгвістика і літературознавство. Бердянськ : Бердянський держ. пед. ун-т, , 2013. Вип. XXVII. Ч. 3. С. 60-68.

127. Мартинець А. М. Національна двозначність Конрада: проблема чи досягнення. Наук. праці Кам'янець-Подільського нац. ун-ту імені Івана Огієнка. Філол. науки. Кам'янець-Подільський : Аксіома, 2013. Вип. 33. С. 206-209.

128. Рега Д. Генеза футуризму в слов'янських країнах. Вісник Прикарпатського унmу. Філологія. Івано-Франківськ : Плай, 2013. Вип. 38-39. С. 102-108.

129. Рега Д. Мотив любові у творчості поетів-футуристів (на прикладі поетичної спадщини В. Маяковського, М. Семенка та Б. Ясенського). Науковий вісник Східноєвропейського нац. ун-ту імені Лесі Украӥнки. Філол. науки. Луцьк, 2013. Вип. 13. С. 88-94.

130. Ткачук Т. Рецепція творчості Станіслава Пшибишевського в українській літературі кінця XIX - початку XX століть. Літературознавчі студії : компаративний аспект / відп. ред. С. І. Хороб. Івано-Франківськ : Симфонія форте, 2013. Вип. 1. С. 54-58.

131. Ткачук Т. Художній доробок Станіслава Пшибишевського в осмисленні та оцінках українських критиків. Література в контексті культури : всеукр. наук. конф.: матеріали. Дніпропетровськ : Литограф, 2013. С. 40-41.

132. Цівкач О. М. Невідомі сторінки творчої діяльності польської письменниці Марцеліни Грабовської. Літературознавчі студї : компаративний аспект / відп. ред. С. I. Хороб. Івано-Франківськ : Симфонія форте, 2013. Вип. I. С. 122-126.

133. Цівкач О. М. (упор.). Стефанія Скварчинська - журналістка «Кур’ера Станіславівського». Невідомі сторінки творчої діяльності (1925-1930). Івано-Франківськ : Симфонія форте, 2013. 227 с. 
134. Ciwkacz O. Марцеліна Грабовська - журналістка «Кур’єра Станіславівського» (1931-1933). Galicja - mozaika nie tylko narodowa / tom studiów pod red. prof. dr hab. Urszuli Jakubowskiej; Instytut Badań Literackich PAN. Warszawa, 2013. S. 183-198.

135. Ciwkacz O. Stefan Żeromski. Tradycja i eksperyment. Idea i układ. Jarosław Ławski. Żeromski. Naukowy projekt wydawniczy - Seria Przełomy. Pogranicza. Studia literackie. Białystok-Rapperswil : Wydawnictwo Alter Studio, 2013. T. VII. S. 51-55.

\section{4}

136. Рега Д. Індивідуальна модель у поезії Б. Ясенського та М. Семенка : компаративний аналіз. Літературознавчі студї : компаративний аспект /відп. ред. І. В. Козлик. Івано-Франківськ : Симфонія форте, 2014. Вип. II. С. 43-48.

137. Рега Д. Місце українського та польського футуризму у системі європейського футуризму. Метаморфози в сучасній украӥнській літературі / за ред. П. Олеховської, М. Замбжицької та К. Якубовської-Кравчик. Варшава; Івано-Франківьк, 2014. С. 14-30.

138. Спатар I. Мотив двійництва у польській та українській новелістиці другої половини XIX - початку XX століття (на прикладі творів Е. Ожешко «Зимового вечора» та І. Франка «На дні», Вісник Прикарпатського ун-ту. Філологія, Івано-Франківськ : ПНУ, 2013-2014. Вип. 40-41. С. 271-278.

139. Ткачук Т. Елементи натуралізму у малій прозі Станіслава Пшибишевського і Василя Стефаника. Вісник Прикарпатського ун-ту. Філологія (літературознавство). Івано-Франківськ : ПНУ, 2013-2014. Вип. 40-41. С. 249-261.

140. Ткачук Т. Контроверсійність сприйняття творчості С. Пшибишевського у польському літературознавстві. Султанівські читання. Актуальні проблеми літературознавства в компаративних вимірах / редкол.: І. В. Козлик (голова) й ін. Івано-Франківськ : Симфонія форте, 2014. Вип. III. С. 170-175.

141. Ткачук Т. Лабіринтами мислення «Ноmo excappans»-героя сучасної польської та української «молодої» прози [Рец. на: Шевчук Я. Homo excappans: Герой сучасної польської та української «молодої» прози, Вид-во ЖДУ імені Івана Франка, Житомир, 2012. 350 с.]. Вісник Прикарпатського ун-ту. Філологія (літературознавство). Івано-Франківськ : ПНУ, 2013-2014. Вип. 40-41. С. 302-304.

142. Цівкач О. М. Літературний портрет Катарини Коссаковської у романі Юзефа Ігнація Крашевського «Мачуха». Волинь-Житомирщина. Історико-філол. зб. з регіональних проблем. Житомир : Вид-во Житомирського держ. ун-ту імені Івана Франка, 2014. Т. 25 : Універсум Юзефа Ігнація Крашевського. С. 236-246.

143. Цівкач О. М. Поетика епітафії на старих польських цвинтарях Галичини. Bicник Прикарпатського ун-ту. Філологія. Івано-Франківськ : ПНУ, 2013-2014. Вип. 40-41. C. 214-220.

144. Цивкач О. Спогади Станіслава Вінценза про Івана Франкаю Нова Польща. Спеціальний український номер. Варшава, 2014. С. 37-43.

145. Ciwkacz O. «Kwasy żołądkowe» forsztehera Wacława Precliczka, czyli o smakach, gustach, zmysłach w powieści Jana Lama «Wielki świat Capowic». Przyjemność $i$ cierpienie. Genus und Qual. Studia i szkice / pod red. nauk. Grzegorza Jaśkiewicza i Jana Wolskiego. Rzeszów : Wydawnictwo Uniwersytetu Rzeszowskiego, 2014. T. 2. S. 67-77.

\section{5}

146. Козлик І., Орнат Н. Топос міста у романах польської письменниці Полі Гоявічинської «Дівчата з Новолипок» та «Райська яблуня». Султанівські читання : зб. статей / редкол.: I. В. Козлик (голова) й ін. Івано-Франківськ: Симфонія форте, 2015. Вип. IV. C. $111-120$.

147. Мартинець А. М. Інтуїтивний підхід як основа творення образу дитини у творчому доробку Бруно Шульца. Мова та література у полікультурному просторі: 
матеріали міжнар. науково-практ. конф., м. Львів, 13-14 лютого 2015 р. Львів : ГО «Наукова філологічна організація „ЛОГОС”», 2015. С. 17-19.

148. Орнат Н. Екзистенційний мотив відчаю в структурі романів Полі Гоявічинської «Райська яблуня» та Ірини Вільде «Сестри Річинські» (порівняльний аспект). Україністика : минуле, сучасне, майбутнє. Брно, 2015. Т. III : Література і культура. C. $199-202$.

149. Орнат Н. Естетика самотності в романах Полі Гоявічинської «Дівчата з Новолипок» та «Райська яблуня». Сучасні дослідження з лінгвістики, літературознавства $i$ міжкультурної комунікації : матеріали II міжнар. наук. конф. ELLIC 2015. Івано-Франківськ : Видавець Кушнір Г. М., 2015. С. 271-272.

150. Рега Д. Слов’янський варіант футуризму : питання самовизначення. Україністика : минуле, сучасне, майбутнє. Брно, 2015. Т. III : Література і культура. С. 221-228.

151. Спатар I. «Про річ маловідому» Елізи Ожешко, або до питання рецепції творчості Тараса Шевченка польською письменницею. Вісник Прикарпатського ун-ту. Філологія. Івано-Франківськ : ПНУ, 2014-2015. Вип. 42-43. С. 240-247.

152. Спатар I. Рецепція образу Кассандри в однойменних драмах Елізи Ожешко та Лесі Українки. Султанівські читання : зб. статей / редкол.: І. В. Козлик (голова) й ін. Івано-Франківськ : Симфонія форте, 2015. Вип. IV. С. 44-51.

153. Ткачук Т. Особливості засвоєння доробку С. Пшибишевського Ольгою Кобилянською і Лесею Українкою. Наукові записки Тернопільського нац. пед. ун-ту імені Володимира Гнатюка. Серія: Літературознавство. Тернопіль, 2015. Вип. 42. С. 40-49.

154. Ткачук Т. О. Станіслава Пшибишевський і Україна. Методичні рекомендації до вивчення творчості С. Пшибишевського на заняттях з історії польської літератури. Івано-Франківськ : Симфонія форте, 2015. 64 с.

155. Ткачук Т. Творчі взаємини Василя Стефаника із Станіславом Пшибишевським. Studia Methodologica. Тернопіль, 2015. Вип. 40. С. 82-88.

156. Ткачук Т. Творчість Станіслава Пшибишевського в літературно-критичній рецепції польських науковців 1898-1903 років. Південний архів. Філол. науки. Херсон : ХДУ, 2015. Вип. 63. С. 96-104.

157. Ткачук Т. Творчість С. Пшибишевського в рецепції І. Франка. Вісник Прикарпатського ун-ту. Філологія (літературознавство). Івано-Франківськ : ПНУ, 2014-2015. Вип. 42-43. С. 271-280.

158. Marcelina Grabowska - dziennikarka «Kuriera Stanisławowskiego» (1931-1933), wstęp, dobór tekstów i kometarz O. Ciwkacz. Iwano-Frankiwśk : Symfoniia forte, 2015. $140 \mathrm{~s}$.

159. Ornat N. Sposób portretyzacji głównych bohaterek w nowelach Poli Gojawiczyńskiej «Dziewczęta z Nowolipek», «Rajska jabłoń» i Iryny Wilde «Sestry Riczynśki» («Siostry Riczyńskie»). Spheres of Culture. Lublin : Ingvarr, 2015. Vol. XII. S. 192-197.

160. Tkachuk T. Stanisław Przybyszewski i Olga Kobylańska: do problemu kulturalnego pogranicza. Султанівські читання : зб. статей / редкол.: І. В. Козлик (голова) й ін. ІваноФранківськ : Симфонія форте, 2015. Вип. IV. C. 44-51.

\section{6}

161. Орнат Н. Архетип матері в романах Полі Гоявічинської «Дівчата 3 Новолипок» та Ірини Вільде «Сестри Річинські». Султанівські читання : зб. статей / редкол.: I. В. Козлик (голова) й ін. Івано-Франківськ : Симфонія форте, 2016. Вип. V. C. 153-164.

162. Ornat N. Поляки і Польща міжвоєнного двадцятиліття у романі Ірини Вільде «Сестри Річинські». Galicja - mozaika nie tylko narodowa. Warszawa : Instytut badań literackich PAN, 2016. Tom III. S. 97-107.

163. Ткачук Т. Іван Франко і Станіслав Пшибишевський. Київські полоністичні студї. Київ, 2016. Т. 29. С. 476-484. 
164. Цівкач О. М. «Цвинтарна література» або поетика епітафії на старих польських цвинтарях Галичини. Волинь-Житомирщзина. Історико-філол. зб. з регіональних проблем. Житомир : Вид-во Житомирського держ. ун-ту імені Івана Франка, 2016. Т. 27. C. 423-423.

\section{7}

165. Мартинець А. М. Ознаки трансферної концепції у романах Ірени Роздобудько «Гудзик» та Януша Вишневського «Самотність в мережі. Триптих». Сучасні дослідження з лінгвістики, літературознавства і міжкультурної комунікації (ELLIC, 2017): матеріали IV міжнар. наук. конф. Івано-Франківськ : Видавець Кушнір Г. М., 2017. С. 118-124.

166. Мартинець А. М. Творчість Джозефа Конрада: до проблеми визначення національних витоків. Літературознавчі студї: компаративний аспект / відп. ред. І. В. Козлик. Івано-Франківськ : Симфонія форте, 2017. Вип. V. С. 50-56.

167. Рега Д. Специфіка викладання курсу «Мережева література» студентам полоністам. Актуальні проблеми професійної підготовки студентів-філологів до роботи в сучасному освітньому просторі. Івано-Франківськ : Симфонія форте, 2017. Вип. 1. С. $104-$ 107.

168. Ткачук Т. Василь Стефаник і Станіслав Пшибишевський: міжкультурний діалог. Василь Стефаник : наближення / під ред. С. І. Хороба. Івано-Франківськ : Місто НВ, 2017. C. 420-434.

169. Ткачук Т. Експресіонізм у малій прозі Василя Стефаника і Станіслава Пшибишевського. Василь Стефаник : наближення / під ред. С. І. Хороба. Івано-Франківськ : Місто НB, 2017. С. 249-272.

170. Ткачук Т. Сприйняття українським літературознавством модерністських ідей Станіслава Пшибишевського (1909-1930рр.). Слово. Прикарпатський вісник НТШ. Івано-Франківськ : Вид-во Івано-Франківського національного технічного університету нафти і газу, 2017. Вип. 3(39). С. 355-365.

171. Ciwkacz O. Dzieje polskiego amatorskiego i zawodowego w Stanisławowie (17451939). Iwano-Frankiwśk : Symfoniia forte, 2017. $400 \mathrm{~s}$.

\section{8}

172. Рега Д. О. Лібература: типологія, поетика. Соціально-гуманітарні науки та сучасні виклики. Матеріали III всеукр. наук. конф. 25-26 травня 2018 р., м. Дніпро. Дніпро : СПД «Охотнік», 2018. Ч. II. С. 199-200

173. Спатар I. «Тон вічної туги», або жіноча меланхолія в новелах Елізи Ожешко «Аскетка» та Ольги Кобилянської «Valse melancholique». Султанівські читання : зб. статей / редкол.: І. В. Козлик (голова) й ін. Івано-Франківськ : Симфонія форте, 2018. Вип. VII. С. 109-119.

174. Spatar I. Historia literatury polskiej drugiej połowy XIX wieku. Pozytywizm. Wskazówki metodyczne do zajęć praktycznych. Iwano-Frankiwśk : Symfoniia forte, 2018. 44 s

\section{9}

175. Мартинец А. М. Художнє оприявлення соціальних викликів у творах Барбари Космовської. Scientific discoveries: projects, strategies and development: Collection of scientific papers $\langle\Lambda \mathrm{O} O \Gamma \mathrm{O} \Sigma$ » with Proceedings of the International Scientific and Practical Conference, Edinburgh, October 25, 2019. Edinburgh, UK: European Scientific Platform, 2019. Vol. 3. C. 21-24. URL: http://rep.btsau.edu.ua/bitstream/BNAU/3548/3/Seman tychni_vidmi. pdf

176. Спатар I. Ідеї жіночої емансипації в літературно-критичній творчості Елізи Ожешко і Наталії Кобринської. Султанівські читання : зб. статей / редкол. : І. В. Козлик (голова) й ін. Івано-Франківськ, 2019. Вип. VIII. С. 34-45. 
177. Ткачук Т. Українські письменниці «зламу віків» про С. Пшибишевського : епістолярний дискурс. Слово. Прикарпатський вісник НТШ. Івано-Франківськ, 2019. Вип. 2(54). С. 229-236.

\section{0}

178. Ткачук Т. Історія польської літератури епох Бароко і Просвітництва. Методичний посібник. Івано-Франківськ : Симфонія форте, 2020. 80 с.

Отже, сьогодні можна констатувати завершення певного еволюційного циклу (періоду) у розвитку літературознавчої полоністики на кафедрі світової літератури і порівняльного літературознавства ПНУ імені Василя Стефаника. Цей етап вже вичерпав свій творчий потенціал і породжує евристичну інерцію. У такій ситуації визначення перспектив полоністичних науково-дослідницьких практик прикарпатських літературознавців, як на мене, пов'язане насамперед зі зміною методологічних орієнтирів, тобто з вирішенням проблем методологічного гатунку.

Водночас треба враховувати, що систематичне літературознавче дослідження художніх практик i творчого досвіду польських письменників на кафедрі світової літератури і порівняльного літературознавства ПНУ імені Василя Стефаника відбувається (попри індивідуальні полоністичні фахові уподобання членів кафедри) насамперед завдяки тому, що на Факультеті філології цього вишу успішно функціонує на бакалаврському і магістерському рівнях спеціальність «Польська мова і література». А тому перспективи розвитку полоністичних студій на кафедрі безпосередньо пов'язані зі зміцненням відповідної навчальної спеціалізації, а також з подальшим розвитком взаємозв'язків між Факультету філологї̈ ПНУ імені Василя Стефаника та польськими вищими навчальними закладами та науковими установами.

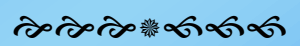

